\title{
Diversify House Heating Mode Comparison and Optimization in Northern China
}

\author{
Shudong Zhang ${ }^{1}$,Jingyan Xuan ${ }^{1}$,Han Song ${ }^{1}$,Yan Zhang ${ }^{1}$,Chengri Jin $^{1}$,Dongzhu Yan ${ }^{1}$ \\ 1.Yanbian Power Supply Company,Yan Ji, Jilin133000,China
}

\begin{abstract}
The air pollution caused by coal-fired heating in the northern cities is again attracting attention. As a new type of heating mode, electric heating enters people's view. In order to make the public understand the characteristics of electric heating, this paper firstly analyzes the technical scheme of electric heating, then takes the project of North China as an example to carry out the economic benefit analysis research, and, according to the appraisal result, gives the government subsidy electricity price proposal. It has important practical reference significance to the electric heating implementation promotion.
\end{abstract}

Keywords-- electric heating; economic benefits; clean energy; subsidized electricity price

\section{INTRODUCTION}

With the depletion of fossil energy, the increasing voice of emission reduction and the increase of the demand for power supply reliability by users, it is urgent to use electric heating to heat the heating system. Electric heating has brought good economic and social benefits in the aspects of energy saving, pollution reduction, and improving the reliability of user power supply. However, the application of electric heating to the actual user heating needs huge investment. Whether the investment is economical depends on whether the comprehensive benefit is greater than the investment. The quantitative evaluation of the comprehensive benefit of electric heating and its cost-benefit analysis can provide a scientific basis for the investment decision of electric heating. It is of great significance to the development of electric heating technology itself or to the development of the power grid construction.

From the northern heating area, the proportion of heating in the scattered boiler room is the largest, and the efficiency of the coal-fired boilers used by the industrial users is usually not high, and the heating of the dispersed coal-fired boilers also causes the low utilization of the fuel. It's very important to change the way of energy consumption and improve the efficiency of energy utilization.

\section{RESEARCH TRENDS OF ELECTRIC HEATING}

The cost-benefit analysis is a kind of assistant planning decision method from the economic perspective by comparing all the expected benefits and all expected costs of the alternative project. In the discussion of the comprehensive benefits of electric heating, the benefits of energy saving, reducing environmental pollution and improving the reliability of power supply are relative to the traditional power generation methods. Considering that coal-fired power generation occupies the main position in the power generation structure of China, the conventional large coal-fired power generation is taken as a reference when evaluating the comprehensive benefits of electric heating. In this paper, the comprehensive benefit of electric heating is defined as: under the condition of supplying the users with the same capacity, the total of the social and economic benefits of electric heating is increased compared with the conventional large-scale coal-fired power generation.

The cost-benefit analysis equation for electric heating is as follows:

$$
G=V-C
$$

Among them, $\mathrm{G}$ is the annual profit of electric heating; $\mathrm{V}$ is the annual economic benefit of electric heating compared with coal-fired power generation; $\mathrm{C}$ is the equal annual value of the increased cost of electric heating relative to coal-fired power generation. The so-called equivalent value refers to the average annual payment in several years.

The formula for converting a currency from its current value to an equal-year value is:

$$
I_{A Y V}=\frac{r(1+r)^{n}}{(1+r)^{n}-1} I_{I N T}
$$

IAYV is the equal-year value; Iint is the initial investment of the project; $\mathrm{n}$ is the payback period; $\mathrm{r}$ is the discount rate, it is the society's estimate of the time value of the fund, the discount rate used in China's current power planning is generally $8 \%$.

\section{COMPREHENSIVE BENEFIT EVALUATION OF ELECTRIC HEATING}

The comprehensive benefit evaluation of electric heating should consider its economic benefit, energy saving benefit and environmental benefit, and the evaluation model is as follows:

$$
V=V_{E C}+V_{E V}+V_{E S}
$$


Among them: $\mathrm{V}$ for the comprehensive benefits of electric heating, VEC for economic benefits, VEV for energy efficiency, the VES for environmental benefits.

\section{A. Economic Benefits}

(1). Initial investment costs

The initial investment cost of electric heating technology mainly includes the cost of land occupation and civil construction, the purchase and installation cost of main equipment and auxiliary equipment, installation and commissioning cost, and the cost of indoor and outdoor network, the initial investment cost I is calculated as follows:

$$
\mathrm{I}=I_{\mathrm{LU}}+I_{\mathrm{LC}}+I_{\mathrm{Eq}}+I_{P l}
$$

1) Land use fee $I_{L U}$
The construction of heating system needs to occupy a certain land, it is necessary to pay a certain cost in order to obtain the right to use the construction land. The main land of the heating system is the land needed for the construction of the heat source boiler room. The size of the occupied land is related to the heating load. The larger the heating load, the larger the area of the equipment needed.

$$
I_{\mathrm{LU}}=p_{1} \times q_{i} \times Q
$$

$\mathrm{p} 1$-land price, yuan $/ \mathrm{m} 2$

qi-the unit thermal load footprint of the boiler room of type I, m2/MW

Q-heating load, W

Table I. Estimating the floor area of various boiler houses $\left(\mathrm{M}^{2} / \mathrm{MW}\right)$

\begin{tabular}{ccccccc}
\hline $\begin{array}{c}\text { Heat } \\
\text { source } \\
\text { Form }\end{array}$ & $\begin{array}{c}\text { Coal-fired } \\
\text { Boiler } \\
\text { room }\end{array}$ & $\begin{array}{c}\text { Gas } \\
\text { Boiler } \\
\text { Room }\end{array}$ & $\begin{array}{c}\text { Heat Pump } \\
\text { Room }\end{array}$ & $\begin{array}{c}\text { General } \\
\text { Electric } \\
\text { Boiler Room }\end{array}$ & $\begin{array}{c}\text { Water } \\
\text { storage and } \\
\text { thermoelectri } \\
\text { c boiler }\end{array}$ & $\begin{array}{c}\text { Solid-state } \\
\text { Thermal } \\
\text { storage Boilers }\end{array}$ \\
\hline $\begin{array}{c}\text { Unit heat } \\
\text { Load } \\
\text { Footprint }\end{array}$ & 150 & 85 & 65 & 50 & 60 & 30 \\
\hline
\end{tabular}

\section{2) Civil cost $I_{L C}$}

Civil engineering cost is the construction cost of building materials, construction labor cost and mechanical equipment cost.

$$
\mathrm{I}_{\mathrm{LC}}=p_{2} \times S
$$

p2-Unit area Construction Price, yuan/m2;

$$
\mathrm{S} \text {-Boiler Room Area, } \mathrm{S}=q_{i} \times Q
$$

3) Equipment cost $I_{E q}$

The cost of the equipment includes the cost of the main body of the boiler and heat pump, the cost of installation and commissioning, and the expenses of purchasing the auxiliary equipment such as circulating water pump, blower and so on.

Indoor and outdoor pipe network fee $I_{P I}$

Heating system pipe Network mainly includes outdoor and indoor pipe network, which should be based on the type of construction and building area specific selection of pipe network materials.

\section{B. Energy Saving Benefit}

First of all, the electric heating using clean energy, which will reduce the consumption of fossil energy; on the other hand, through the comprehensive utilization of energy, which will greatly improve the efficiency of energy use.
The energy efficiency of electric heating in electric energy production links is defined as: Compared with conventional coal combustion, electric heating supplies the value of fossil energy that is equal to electricity and heat energy.

$$
V_{E V}=M_{c} p_{c} B
$$

Mc for the amount of coal consumed by generating units of thermal power units; Pc for the coal price; and B for the electricity consumption of electric heating and heating period.

\section{Environmental Benefit}

In China's energy generation structure, coal accounts for the largest proportion and provides about $80 \%$ of the electricity. The main pollutants of coal-fired power generation are $\mathrm{S} 02$, NOX, C02, CO, fly ash and so on. The air pollution caused by a large number of coal-fired power plants has seriously affected and damaged the environment for human survival. The use of clean energy in electric heating can

\begin{tabular}{|c|c|c|c|c|}
\hline & $\mathrm{CO} 2$ & SO2 & $N O X$ & $T P S$ \\
\hline $\begin{array}{c}\text { Coal-fired boiler } \\
\text { room } \\
(\mathrm{g} / \mathrm{kgce})\end{array}$ & 2500 & 10.2 & 4.19 & 2.26 \\
\hline $\begin{array}{l}\text { thermal power } \\
\text { plant }(\mathrm{g} / \mathrm{kgce})\end{array}$ & 2500 & 0.85 & 3.95 & 1.79 \\
\hline
\end{tabular}
greatly reduce the discharge of pollutants and has considerable environmental value.

Table II. Pollutant emission factors of different forms of standard coal and natural gas combustion

(1)Calculation of pollutant emission 
The coal-fired heating mainly in coal as fuel, coal will produce large amounts of TPS, SO2, CO2, NOX and other pollutants in the combustion process, have a greater impact on the environment. This section will calculate the amount of air pollution caused by coal-fired boilers.

\section{TPS emission calculation}

The calculation formula is as follows:

$$
\mathrm{Q}_{\mathrm{TPS}}=\frac{\mathrm{d}_{\mathrm{fh}} \times \mathrm{B} \times \mathrm{A} \times \eta_{1}}{\left(1-\mathrm{C}_{\mathrm{fh}}\right)}
$$

$\mathrm{Q}_{\mathrm{TPS}} \longrightarrow$ Representing the emission of smoke and dust, $\mathrm{kg}$;

B — Representing the amount of coal consumption, $\mathrm{kg}$;

A-Representing the dust content in coal and takes $25 \%$.

$\eta_{1}$ _ Representing the dedusting efficiency of the dedusting system, $\%$;

$\mathrm{C}_{f h}$ - Representing the carbon content in the dust, and takes $30 \%$.

$d_{f h}$ Representing $25 \%$ of the total ash content in soot.

The calculation of SO2 emissions from coal combustion:

The composition of sulfur in coal can be divided into combustible sulfur and non combustible sulfur, and combustible sulfur accounts for about $80 \%$ of total sulfur content. The formula for calculating sulfur dioxide emissions from coal combustion is as follows:

$$
\mathrm{Q}_{\mathrm{SO}_{2}}=2 \times 80 \% \times \mathrm{B} \times \mathrm{S} \times\left(1-\eta_{2}\right)
$$

$\mathrm{Q}_{\mathrm{SO}_{2}} \longrightarrow$ Representing the emission of sulfur dioxide, $\mathrm{kg}$;

B__ Representing the consumption of fuel coal, $\mathrm{kg}$;

$\mathrm{S}$ - Representing the total sulfur content in the fuel, $\%$;

$\eta_{2} \ldots$ Representing the removal rate of sulfur dioxide in the desulfurization unit.

Calculation of NOX emission from coal combustion

$$
\mathrm{Q}_{\mathrm{NO}_{\mathrm{x}}}=1.63 \times \mathrm{B} \times\left(\rho_{\mathrm{N}} \times \eta_{3}+0.000938\right)
$$

$\mathrm{Q}_{\mathrm{NO}_{\mathrm{X}}}$ Representing the emission of nitrogen oxides, $\mathrm{kg}$;

B__ Representing the consumption of fuel coal, $\mathrm{kg}$;

$\rho_{\mathrm{N}}$ - Representing the content of nitrogen in the fuel, $\%$; $\eta_{3}-$ Representing the $\mathrm{NO} x$ conversion rate of nitrogen in coal, $\%$.

The calculation of $\mathrm{CO} 2$ emissions from coal combustion:

$$
\mathrm{Q}_{\mathrm{CO}_{2}}=\mathrm{B} \times \mathrm{J} \times \mathrm{E} \times \mathrm{K}_{\mathrm{CO}_{2}} \times \lambda_{\mathrm{CO}_{2}}
$$

$\mathrm{Q}_{\mathrm{CO}_{2}}-$ Representing the emission of $\mathrm{CO} 2, \mathrm{~kg}$;

B_-Representing the coal consumption, $\mathrm{kg}$;

$\mathrm{J} \_$Representing the unit calorific value of coal, $\mathrm{MJ} / \mathrm{kg}$;

E_- Representing the potential carbon emission per unit calorific value, $\mathrm{kg} / \mathrm{TJ}$.

$\mathrm{K}_{\mathrm{CO}_{2}}-$ Representing the oxidation rate of carbon in fuel;

$\lambda_{\mathrm{CO}_{2}}$ Representing The molar mass ratio of $\mathrm{CO} 2$ to $\mathrm{C}$, about 3.667 .

(2) Calculation of environmental value of pollutant discharge

Environmental value refers to the value of pollutant emission reduction itself, and the environmental value is different from that of sewage charges and far greater than that of sewage charges. This section estimates the environmental value standards of pollutants from coal-fired boilers based on domestic and foreign literature and referring to the total pollutant discharge standard. The following is shown in Table III.

Table III. Environmental standards for pollutant emission reduction in the power industry (yuan $/ \mathrm{kg}$ )

\begin{tabular}{cccccc}
\hline Contaminants & $\mathrm{SO} 2$ & $\mathrm{NOX}$ & $\mathrm{CO} 2$ & $\mathrm{CO}$ & dust \\
\hline $\begin{array}{c}\text { environmental } \\
\text { value }\end{array}$ & 6.00 & 8.00 & 0.23 & 1.00 & 0.12 \\
& & & 0 & & \\
\hline
\end{tabular}

(3) Quantitative analysis model of environmental benefits

The environmental benefits of electric heating can be measured by the environmental loss of pollutants that are reduced by the same capacity electricity generated by coal-fired power generation. The formula for calculating the environmental benefits of electric heating is as follows:

$$
V_{E S}=\sum_{i=1}^{n} V_{E S} Q_{i}^{c}
$$

VES - Representing the environmental value of pollutant emission reduction in item I, yuan;

$\mathrm{n}$ - Representing the types of pollutants;

Qic_-Representing the pollutant discharge of item I of coal fired unit, $\mathrm{kg}$.

\section{EXAMPLE ANALYSIS}

Taking Helong City, Yanbian as an example, the total area of the building is $8.36 \times 105 \mathrm{~m} 2$, and the heating period is 183 
days. The following is the 2016-2017 year temperature change trend of Helong city.

(1)The total area of dormitory, office and other public utilities management and affiliated housing is $1.87 \times 105 \mathrm{~m} 2$, and the thermal load of heating design is $5.9 \mathrm{MW}$.

(2)The area of the canteen is $0.69 \times 105 \mathrm{~m} 2$, and the thermal load of heating design is $2.3 \mathrm{MW}$.

(3)The plant area is $5.8 \times 105 \mathrm{~m} 2$, and the thermal load of heating design is $19.7 \mathrm{MW}$.

The total design heat load of the building is $27.9 \mathrm{MW}$. The relevant data of electricity consumption in Helong city are shown in Table IV.

Table IV. Related data for evaluating the efficiency of electric heating

\begin{tabular}{|c|c|c|}
\hline parameter & Numerical & \\
\hline $\begin{array}{l}\text { TCE fuel Price } \\
\text { (yuan/t) }\end{array}$ & 770 & \\
\hline $\begin{array}{l}\text { II type bituminous } \\
\text { coal fuel price } \\
(\text { yuan/t })\end{array}$ & 468 & \\
\hline $\begin{array}{c}\text { Fuel calorific value } \\
\text { of electricity } \\
(\mathrm{MJ} / \mathrm{kWh})\end{array}$ & 3.6 & \\
\hline Price of electricity & $\begin{array}{c}\text { General Electric } \\
\text { Boiler (yuan/kWh) } \\
\text { Solid regenerative } \\
\text { type Electric boiler } \\
(\text { yuan } / \mathrm{kWh})\end{array}$ & 0.28195 \\
\hline
\end{tabular}

Water regenerative

Type Electric boiler (yuan/kWh)

Heating enterprise sales revenue mainly refers to the heating income, for the Yanbian city heating price, residents according to the heating area of 3129 yuan $/ \mathrm{m} 2$, commercial users and institutions and institutions, social groups according to the construction area of $38 \mathrm{Yuan} / \mathrm{m} 2$, Helong industrial zone belongs to the residents type of dormitory building area $1.24 \times$ $105 \mathrm{~m} 2$, according to the ratio of residential heating area and building area (84.13\%), the heating area is about $1.04 \times 105 \mathrm{~m} 2$. After calculation, the sales revenue of HeLong city area is $3.028 \times 107$ yuan

For non resident customers, the use of energy storage equipment can be used to implement the standard of living electricity for residents. The peak period is 8 hours (7:30 11:30), and the trough period is 7 hours (22:00-5:00), and the rest period is 9 hours. Taking 10 thousand volt customers as an example, the valley electricity price per day is 0.28195 yuan $/ \mathrm{kwh}$, the peak period electricity price is 0.78285 yuan $/ \mathrm{kWh}$, and the normal period is 0.5324 yuan $/ \mathrm{kWh}$.

It is estimated that the evaluation results of electric heating costs and comprehensive benefits in Helong District of Yanbian are shown in Table V below.

Table V. The results of electric heating cost and comprehensive benefit evaluation

\begin{tabular}{lccccc}
\hline $\begin{array}{c}\text { Electric } \\
\text { heating type }\end{array}$ & $\begin{array}{c}\text { Annual value of } \\
\text { construction } \\
\text { cost }\end{array}$ & $\begin{array}{c}\text { The } \\
\text { comprehensive } \\
\text { benefit of the year } \\
571.327\end{array}$ & $\begin{array}{c}\text { Economic } \\
\text { benefits }\end{array}$ & $\begin{array}{c}\text { Energy } \\
\text { Saving } \\
\text { Benefits }\end{array}$ & $\begin{array}{c}\text { Environmental } \\
\text { benefits }\end{array}$ \\
$\begin{array}{l}\text { Ordinary } \\
\text { electric boiler }\end{array}$ & 763.65 & 1825.997 & -210.88 & 1175.01 & 861.867 \\
$\begin{array}{l}\text { Solid } \\
\text { regenerative } \\
\text { electric boiler }\end{array}$ & 769.85 & & & & 818.17 \\
$\begin{array}{l}\text { Water } \\
\text { regenerative } \\
\text { electric boiler }\end{array}$ & 747.49 & 1863.187 & -173.69 & 1175.01 & 861.867 \\
\hline
\end{tabular}

It can be seen from the above table that although the investment cost of electric heating is high, the investment of electric heating can be economic if it is from the perspective of the whole society, considering the benefits of electric heating in improving reliability, saving energy and reducing consumption and protecting the environment. The development of electric heating can not rely on the unilateral power of the user or the Power Grid Corp. The government should take the necessary measures to combine the power of various stakeholders in order to promote the healthy development of electric heating.

\section{CONCLUSION}

Based on the conventional large-scale coal-fired power generation, from the perspective of the whole society, the benefits of electric heating in energy saving, environmental protection and other aspects were quantitatively evaluated, and the comprehensive benefit evaluation model of electric heating was put forward. By analyzing the cost-effectiveness of ordinary electric boilers and thermal storage electric boilers, the following conclusions are drawn:

(1) The economy of electric boiler is good. Under the condition of abundant power resources and sufficient heating 
area, the industrial users should use electric boiler for heating, which can get better economy.

(2) The investment cost of electric heating is high, but the investment of electric heating can be economic if it is from the point of view of the whole society, considering the benefits of electric heating in improving reliability, saving energy and reducing consumption and protecting the environment. The development of electric heating also needs the promotion of the government.

\section{REFERENCES}

[1] Chu K, Kim D, Sohn Y, et . al Electrical and Thermal Properties of Carbon-Nanotube Composite for Flexible Electric Heating-Unit Applications[J]. IEEE Electron Device Letters, 2013, 34(5): 668-670.

[2] Cong Yanhui, Zhang Qibin. Analysis on the experience of electric heating technology application[J].Innovation and application of science and technology,2016(29): 140-140.

[3] Lv Weisi, Chen Yuntao. Analysis of application of electric heating technology in China[J].Innovation and application of science and technology,2016(29) : 151-151.

[4] Sanbao Y E, Diao Y, Zhao Y. Heat Storage-Release Property of Phase-Change Thermal Storage System with New Flat Heat Pipe[J]. Electric Power Construction, 2014, 35(7): 136-140.

[5] Yang W, Sun L, Chen Y. Experimental investigations of the performance of a solar-groundsource heat pump system operated in heating modes[J]. Energy \& Buildings, 2015, 89: 97-111.

[6] Bi Y, Chen L, Wu C. Heat source performance for solar-ground source heat pump[J]. Journal- Energy Institute, 2016, 78(4) : 185-189.

[7] ]Hein P, Kolditz O, Görke U Jet al. A numerical study on the sustainability and efficiency of borehole heat exchanger coupled ground source heat pump systems[J]. Applied Thermal Engineering, 2016, 100: 421-433. 